\section{On Peasants and 'Primitive Peoples': Moments of Rapprochement and Distance between Folklore Studies and Anthropology in the Netherlands}

\section{Rob van Ginkel \& Barbara Henkes}

University of Amsterdam, the Netherlands

ABSTRACT Fruitful exchanges of ideas existed between early 20 th century anthropology (volkenkunde) and folklore studies (volkskunde) in the Netherlands. Folklorists proposed using the fieldwork methods and comparative approach of ethnography. Anthropologists thought folklore studies might be able to shed light on survivals of earlier stages in their own society. During the 1930s, however, anthropologists turned their backs on the evolutionist paradigm, while in the wake of National Socialism and its quest for a common Germanic race and culture folklorists limited their cross-cultural comparisons to Europe. Cultural politics in Germany and other European countries in the 1930s and early 1940s directed the concepts, methods and institutionalization of folklore studies, and consequently led to a distancing from the concepts and practice of cultural anthropology.

KEYWORDs Folklore studies, anthropology, the Netherlands, Nazi cultural politics

It has been common practice for ages now to send scientifically equipped expeditions to the most remote corners and deepest interior of our overseas territories to study the habits and customs of what we refer to as primitive tribes ... But the first scientifically oriented folklore expedition in our own country has yet to be conducted! In our colonies we have often and quite rightly studied the practices of the 'primitive' and 'semi-primitive' subjects of Her Majesty the Queen, but up to now we have remained virtually ignorant as regards the recurrently observed identical and no less interesting practices of the 'civilized' inhabitants of the mother country!

$\mathrm{T}$

hese comments were made by folklorist Dirk Jan van der Ven, who formulated his views on folklore studies in 1930 in the new multidisciplinary Dutch journal Mensch en Maatschappij (Man and Society I930a:458). His line of reasoning reveals a covert jealousy of the anthropologists who - in the wake of colonial interests - had already gained recogni- tion and funding for their discipline at the time. His envy is also evident in another publication dated that same year, where Van der Ven compares the 'extremely well-documented monographs on the primitive and semi-primitive tribes in our colonies in the East and West' and the dearth of knowledge about 'social relations among the islanders of Marken' [a Dutch island renowned for its 'exotic' material culture]. On the grounds of this observation, he concludes: 'the study of national folklore has always been considered less important than the anthropological study of our colonies' (I93 ob:20). He feels this situation calls for change. According to Van der Ven, the Netherlands Open Air Museum in Arnhem should be a center for research on questions involving the Netherlands and its people in much the same way as the Colonial Institute in Amsterdam is a center for the study of questions involving the Netherlands East Indies (now Indonesia). ${ }^{1}$

In comparison with the anthropological research conducted outside the Netherlands, Dutch folklore studies was indeed a field that had yet to be developed. It was primarily practiced by enthusiastic autodidacts often specialized in a specific region or theme, although several academics had made efforts to provide the field with a theoretical perspective. Van der Ven was not university educated himself, but he did back the idea of turning folklore studies into a professional and institutionalized field. In their efforts to achieve this goal, folklorists received support from anthropologists who saw possibilities for anthropology 'at home'.

In this article, we examine the relations between folklore studies (volkskunde) and anthropology (volkenkunde) during the interwar period and the Nazi occupation. ${ }^{2}$ Inspired by anthropological fieldwork methods, folklorists moved closer to anthropology. They felt they should follow the example set by anthropologists and go out into 'the field'. What is more, some folklorists liked to compare aspects of their own present-day culture with those of distant times and places. This comparative approach oriented them all the more towards the work of anthropologists. In turn, the latter could envision the contribution folklore studies might make to some of the questions they were interested in from an evolutionist perspective. In the twenties and thirties, a relatively intensive exchange of ideas thus developed between folklorists and anthropologists. Personal and institutional contact became increasingly intensive. Before the end of the thirties, however, representatives of the two disciplines that had made every effort to come closer together were dissociating themselves from each other. The use of a comparative perspective played an important role in this connection, with the issue being debated of

ETHNOS, VOL. 68:I, 2003 (PP. II2-I34) 
whether or not any comparisons could indeed be drawn between Dutch folk culture (volkscultuur) and 'primitive' cultures elsewhere. Besides these innerdisciplinary developments, the dissociation between folklore studies and anthropology was stimulated by the rise of National Socialism and its quest for common Germanic roots. We examine how the ambivalent relation between the two disciplines manifested itself under the influence of academic debates and cultural politics.

\section{Van der Ven and the Folklore Field Worker}

The Van der Ven who propagated an 'anthropology of the Netherlands' was already a well-known folklorist. He was actively involved with the Netherlands Open Air Museum that opened in Arnhem in r9I8. On the grounds of the Open Air Museum, a bit more than a year later he organized a National Historical Folklore Festival, where delegations from all eleven provinces in the Netherlands demonstrated the specific 'traditions' still in evidence in their regions. This seven-day folklore performance turned into a mass event attended by hundreds of thousands of spectators. Like the Open Air Museum, its aim was to demonstrate the 'unity in diversity' of the Dutch people and arouse their interest in their own national and regional cultures.

Van der Ven's efforts coincided with the growing interest in folklore studies that was beginning to emerge in the Netherlands in much the same way as it had elsewhere in Europe. This trend was linked to the process of modernization. The possibilities generated by industrialization, rationalization, urbanization and new forms of communication were accompanied by concern about the decline of traditional communities and the loss of a lifestyle and material culture that went with them. In this climate, 'reason' and 'romanticism' vied for primacy. In folklore studies, this was expressed in a sharp focus on rural community life and the authentic and static folk culture attributed to it. As opposed to the degenerate 'asphalt' culture of the city, there was the unspoiled, 'natural' culture of the countryside where life was still pure. The important thing was to make every effort to preserve this folk culture in order to reinforce Dutch nationhood and elevate the Dutch people.

Van der Ven was not only one of the most renowned Dutch folklorists in the twenties and thirties, he was also one of the most controversial. This mainly had to do with his popularizing activities. Some scholars viewed him as a dilettante without an academic diploma who was putting folklore studies to shame. They wrote off his successful folklore festival at the Open Air Museum as a 'banal masquerade' (De Jong r992:r6o). Van der Ven was quite aware of the difference between an authentic festivity and one that was staged, but he still viewed the folklore festival as an important instrument for promoting wide public interest in folk culture (Wagemakers 1996). What is more, he felt the folklore festival could stimulate the revival of local customs, which he deemed a good thing.

In addition to his activities targeting a wide audience, Van der Ven devoted a great deal of time and energy to getting folklore studies acknowledged as an academic discipline. He was, as already noted, inspired in this connection by the research methods used by anthropologists. The folklorist, he argued, should 'go out into the field' to study folk customs 'on the spot', devoting attention to diffusion, changes, key figures and acts (Van der Ven 1029a: 272, 274). 'A basic requirement [in the study of Dutch folklore] is that is a biological folklorist, ${ }^{3}$ the researcher should frequently leave his study and go out into the field and should never describe or explain folk customs without having personally experienced them first' (Van der Ven r929b:I47). Personal contact is thus required between the 'scientific folklorist' and his 'living subjects', although quite a bit of skepticism on their part would first livive to be allayed. This is why folklore field workers should not be in any hurry and should try to gain the confidence of their informants. Once they nucceed in doing so, they can 'objectively evaluate, analytically research and oritically compare the facts they have observed with the observations made luewhere in the Netherlands and abroad' (ibid.:I47). To Van der Ven, folklore was 'first and foremost a comparative science and by way of the careIil formulation of analogies and parallels, anthropology, ethnology, folk puychology with philology and mythology are also included in the work field of the scientific folklorist' (ibid.:III). It is interesting that Van der Ven felt that folkloristic parallels of this kind could serve to strengthen patriotism and simultaneously to weaken national chauvinism. In other words, 'Our pattiotism will be reinforced by the study of local customs and folklore, but at the amo time the study of folklore will keep the serious practitioners from overestimating what is theirs and underestimating what is alien to them' $(1 \mathrm{i}+190)$;

Van der Ven was initially quite well informed about the latest development ubrond in the fields of anthropology and folklore studies. In fact he helped introduce the work of the renowned French folklorist and anthropologist Annold van Gennep in the Netherlands, especially the latter's noImno concerning rites of passage (cf. e.g. Van der Ven r927, r929b). Van Gennep moplrad him to emphasize the importance of conducting fieldwork and it 
seems more than likely that Van der Ven shared Van Gennep's idea that 'folklore is the ethnography of European rural populations' (Van Gennep quoted in Belmont I979:7r). In his pursuit of 'salvage ethnography', Van der Ven was quick to discover the scientific potential of photography and film, and made a number of documentaries as early as the twenties. Van der Ven found shooting films 'one of the most objective ways to register folklore material in a certain framework' (1930a:466). He was not that interested though in the reliability aspect. In his films as well as his written work, he was a master in interpreting data to fit a preconceived outline (see Voskuil I98I).

\section{The National Bureau and the Folklore Division}

The Netherlands National Bureau for Anthropology (NNBA), founded in I922 as a national branch of the Institut International d'Anthropologie, helped fund Van der Ven's films. The NNBA had six divisions, which shows the extent to which folklore studies and anthropology were institutionally linked to each other and to other disciplines at the time. There was the Physical Anthropology and Anthropogeography Division, the Ethnography and Ethnology Division, the Folklore Division, the Genetics and Eugenics Division, the Sociology and Criminology Division and the Archaeology Division. Van der Ven was appointed to the board at the Bureau for Anthropology and was Chairman of the Folklore Division there. He was the pivot of a whole series of activities, including folklore courses, lectures, conference meetings, folklore excursions and so on.

Since 19I4, the Anthropology Institute in Utrecht kept a 'systematic card catalogue of ethnology all across the globe'. In addition to themes in the field of anthropology, folklore in the Netherlands was an important part of it, with such categories as farmhouses, pilgrimages, processions and weddings (cf. Rasch I930). Steps of this kind on the part of the Institute demonstrate that there were close ties at the time between folklore studies and anthropology, and not only within the Bureau for Anthropology. The NNBA was nonetheless instrumental in the professionalization of folklore studies. It was within the NNBA framework that a certain extent of structural exchange first took place among Dutch folklorists. Not only were the joint efforts to advance the field reinforced, there was also an exchange on the approaches and methods of the various folklorists and between folklorists and anthropologists. This occurred for instance in a series of lectures for the folklore studies course in I929. Sebald Rudolf Steinmetz, a member of the board of the NNBA who had been a professor of 'political geography, anthropology, and the geography and anthropology of the Dutch East Indies' since I907 at the University of Amsterdam, was one of the speakers. Steinmetz did see the merit of folklore studies that would use anthropological methods to examine Dutch society and culture. As proponent of a comparative approach, Steinmetz held that studying 'primitive peoples' ('natuurvolken') could shed some light on the prehistory of 'civilized peoples' ('kultuurvolken').

In his lecture on anthropology and folklore, Steinmetz alluded to the conceptual system of the French philosopher Lucien Lévy-Bruhl when he noted that folklore was the product of a 'primitive mentality' characterized by associative thinking and a lack of a critical capacity. He went on to say that this mentality could be observed in 'primitive man' as well as the less advanced segments of modern society. His approach was in keeping with the evolutionist version of history, according to which 'primitive peoples' were at a less advanced stage of civilization than 'civilized peoples' (Steinmetz 1929). Moreover, Steinmetz was a supporter of the relic theory, as is evident from his conception of folklore studies as 'the discovery and recording of customs, practices, thoughts, art, yes perhaps of feelings as well, of the relics of older cultures in in newer one, in our culture, and also the study of them, and the dissemination, the explanation, the discovery of regularities in all of them' (ibid.:26r).

Unlike Steinmetz, anthropologist Henri Th. Fischer did not see folklore studies as 'the anthropology of civilized peoples'. Whereas Steinmetz compured primitive culture to folk culture, Fischer noted that in primitive cultures, there was also evidence of 'high' and 'low' culture, for example folk religion and the religion of priests and priestesses (Fischer 1933:430). Fischer did agree though with Steinmetz and folklorists such as Van der Ven that anthropology provided comparative material that could help clarify the original meaning of cultural relics or 'survivals' in their own European culture:

If we are to properly evaluate the superstition of an inhabitant from the province of Drenthe, Groningen or Zeeland, parallels with the beliefs of primitive peoples ean play an important role. Comparisons of this kind can make it easier to underhitand village justice practices and local forms of land ownership (ibid.:430).

In the twenties and early thirties, several anthropologists went along with thit line of thinking. They also often consulted the writings of such famous nineteenth-century evolutionist anthropologists as James G. Frazer, Lewis Henry Morgan and Edward B. Tylor. Tylor's Primitive Culture (187r) is an wample of a work where much of the attention was focused on cultural rellot and 'survivals' from the distant past of British society. Working from the 
idea that present-day society had already gone through any number of developmental stages, greater knowledge of the civilization patterns of primitive peoples might be useful.

However, unilinear evolutionism and diffusionism had increasingly come under fire from anthropologists, especially those based in Leiden. Inspired by the writings of French sociologists Emile Durkheim and Marcel Mauss, they developed an early form of structuralism. Under the leadership of Prof. J.P.B. de Josselin de Jong, they worked on a perspective that regarded culture as an integrated whole governed by structural principles (De Ruijter I98I). Doing fieldwork became part and parcel of their anthropological métier. In as far as comparison was important, they compared cultural phenomena within 'anthropological study fields' (or 'culture areas'). Although Van der Ven had referred to ethnographic fieldwork as if it was common practice among Dutch anthropologists, in fact in the twenties it was still more the exception than the rule. Those anthropologists who favored an engagement with folklore studies - among them Steinmetz and Fischer - could not boast about having done fieldwork at all. They mainly used secondary sources. The cross-cultural comparative work of these 'armchair anthropologists' aimed at coming up with a catalogue of cultural differences and similarities. Both Steinmetz and Fischer's predecessor, J.F.H. Kohlbrugge, began composing ethnographic atlases but due to the infinity of the task failed to complete them.

Leiden anthropologists strongly focused on Indonesian society and culture and catered to the needs of colonial authorities by training colonial civil servants: 'the growing need of colonial administrations for cogent and objective information on the peoples they ruled was conveniently matched by the requirements of anthropologists seeking suitable locations for the collection of ethnographic data' (Ellen r976: 303 ). The practical and applied aspects of their ethnographic inquiries required direct observation, hence their emphasis on the importance of conducting fieldwork. The consequence was that they turned away from the broad comparisons and schemas of evolutionism that had interested an older generation of Leiden anthropologists. Apart from these anthropologists, there was at least one student of folklore who was also critical as regards the basic tenets of evolutionist thinking.

\section{De Vries and Folklore Studies as the Study of Dynamic Processes}

The commonly accepted view of folklore studies as the study of relics and survivals was very different from the idea held by Prof.Jan de Vries from Leiden. De Vries was a scholar of proto-Germanic literature, and it was mainly the study of fairy tales and stories that drew him into folklore studies. In a lecture on the relation between folklore and 'higher' culture, De Vries (I929b) emphasized their dynamic interplay. He thus refuted the notion that folklore studies focuses on the relics of a primitive culture. De Vries held that folk culture largely consists of elements that originated in the higher culture, and that 'there are ample elements from foreign cultures, be it that they have been dispersed among the people via the better educated segments of the population, who incorporate cultural components from abroad' (r932:456). He noted that it would be possible 'to demonstrate influences of this kind and thus to precisely restrict what is truly typical of a specific people. Whatever is left after all these acquired cultural elements are eliminated presents a more accurate picture of a local folk culture than the heterogeneous mixture of presentday tradition' (ibid.). Alluding to the thesis of the German folklorist Hans Naumann about the gesunkenes Kulturgut, De Vries emphasized that it implied a certain degree of contempt in the sense that a rural population is often supposed to be quite satisfied with an urban elite's hand-me-downs. Folklore studies was thus felt to be little more than 'a study of forms of degeneration' (ibid). De Vries suggested a middle position so he could study true folk elements as well as degenerated cultural components, be it from a more dynamic vantage point:

The infinite amount that has been lost in the course of the centuries, that is precisely what is not viable; but the other part that is preserved by tradition is alive and consequently subject to constant growth and change. It can develop in all directions, connect with other elements of completely different origins, adapt to new circumstances, and lastly change as regards form and contents alike. [...] Thus the true study of survivals should not be conducted on the basis of a certain kind of antiquarian interest. We should not analyze material in chronologically separate layers, but should try and comprehend it as a living whole. Then and only then will it be possible to attribute each part its function and significance (ibid.:463).

To De Vries, the most important question was not where cultural influences come from, but how a people assimilates them, why they are incorporated into the culture of a people, and what changes take place in the course of this process (1937b:9). De Vries was thus rejecting the 'relicology' so popular in folklore studies and in part of the field of anthropology. He criticized the lack of reflection on the side of folklorists at the time, who indiscriminately adopted the tendency of the Grimm Brothers and the anthropologist James Frazer to emphasize the heathen origins of folk customs, and felt that instead of cheap theories and unproven hypotheses, there finally ought to be

RTHNOS, VOL. $68: x, 2003($ PP. IX2-r34) 
research based upon facts' (De Vries I934:7). He noted that 'A custom is not explained by simply being labeled "heathen", it is explained by being examined in its present function in the life of the folk community. If it is properly conceived, folklore studies is thus a part of the cultural history of the present, and it is not the "what" but the "how" that interests us. We will consequently have to strive for cultural morphology'. In addition, he had a strong aversion to what he called the 'chaotic collection of street announcements and plant lore, of ingveonisms [examples of North Sea Germanicness] and folk prints, of puppet shows and magic spells' that folklorists are in danger of losing themselves in (De Vries I933:621).

De Vries realized that as a new science, folklore studies had yet to clearly outline its subject matter, develop its methodology and formulate its aims. To do so, it would have to position itself between cultural history and anthropology. In his opinion, folklore studies was distinguished from anthropology to a certain extent by the fact that the latter focused on 'primitive' peoples and folklore studies on 'modern civilized' peoples. Though he was convinced that in part, folklore studies would be wise to turn to anthropology for comparative material, he denounced anthropologists for believing that research on primitive societies would be able to shed any light on general basic cultural patterns, since 'even at the lowest levels of civilization we find cultural phenomena of a highly complicated nature that in some sense can be viewed more as subsidiary than as prior forms of higher civilizations' (1932:454). Moreover, he disqualified much of the ethnographic material as being unreliable (ibid.:460 ff.). De Vries also objected to the ease with which ethnographic comparative material was used and parallels were presented as 'explanations' without any knowledge of the nature and contents of the matters being studied, which could have grown from 'totally different roots' (ibid.:462).

De Vries followed the latest developments in the field in Germany at the time. Efforts were being made there to transform folklore studies into an autonomous discipline by providing it with its own methodology involving such instruments as folklore questionnaires and folklore atlases, which were designed to record the geographic distribution of cultural phenomena. Instead of arbitrarily inventorying elements of Dutch folk culture and trying to find out something about their origins, De Vries felt folklorists should concentrate on the function, meaning, connection and interaction of cultural phenomena and on how they are borrowed, appropriated and mixed. He also pointed out the need for syntheses and advocated comparative research. $\mathrm{He}$ wanted to found folklore studies upon a combination of anthropological, so- ciological, historical geographical and psychological approaches, and without overlooking aspects of the 'living culture' (cf. De Vries 1929a, 1929b, 1937b).

In this sense, De Vries proved to be innovative. At the same time though, his penchant for the study of peasants, fishermen and bargees as 'folk groups that have remained outside the great path of progress and among whom old lifestyles have largely been preserved' (I937a:3-7) was indicative of an unmistakably romantic yearning for authentic qualities. The underlying idea was that 'the people' (het volk) did not consist of 'the mass of nine million Dutchmen who live within our national borders' but of the segment that had best preserved its 'typical character traits' (ibid.). Like many of his contemporaries, De Vries viewed folklore studies as a typically 'national' science that could contribute towards patriotism and national consciousness. He called for more instruments to be used in the practice of this discipline. After all, 'there are young people who have just as much interest in the culture of their own people as they do in the culture of the Sumerians and the Papuans' (De Vries $1937 \mathrm{c}: 4 \mathrm{II})$.

Whereas many anthropologists were out to find the 'noble savage', folklorists were interested in the 'noble peasant'. Their quests were however both based on the same desire to discover 'authenticity' albeit in different contexts. The 'primitive within' and the 'exotic other' were juxtaposed and thought of together in much the same way as in France, where the Musée d'Ethnographie du Trocadéro 'presented the exotic and the picturesque on an equal footing' (Segalen I999:83). The Museum's collection harbored both anthropological and folkloristic artifacts and objects and next to the Salle d'Asie and the Salle dAfrique there was a Salle de France. The situation reflected the evolutionist ideas that 'primitive' culture could shed light on supposedly pre-Christian nurvivals in one's own society. However, like De Vries in the Netherlands, Arnold van Gennep challenged Frazerian comparisons that established parallels between phenomena on the basis of appearances (Cuisenier \& Segalen 1986:16). Not only in France but also in the Netherlands, anthropology and folklore studies would soon begin drifting apart.

\section{The Cartographic Method and the Folklore Atlas}

Once he was on the folklore track, De Vries emerged in the thirties as a prominent scholar in the field. Via his international contacts, he was well versed in how folklore studies was organized in other countries, especially in Seandinavia and Germany. De Vries (I929a) advocated setting up a 'central body' to play a leading role in documenting and researching the folklore field

HTHO\&, VoL. 68:I, 2003 (PP. II2-I34) 
and to launch a Dutch Folklore Atlas analogous to the German Folklore Atlas, the Atlas der deutschen Volkskunde, initiated in 1928 . This German initiative gave a huge fillip to the development of folklore studies in Europe (for France, see Segalen 1986:5). On the basis of questionnaires, distributed throughout Germany with the support of local authorities, churches and schools, specific customs were inventoried and identified as distinct 'cultural and racial territories'. In this way the Atlas contributed to a regional 'folk' culture and it consequently had an identity-building function (cf. Gansohr-Meinel 1995). This meant that scholarly interests and nation-building politics got entangled. However, the academics involved were convinced that the cartographic method introduced an objective scientific approach.

Besides De Vries, other folklorists also promoted the project of a Dutch Folklore Atlas. In November 1934 the Royal Netherlands Academy of Sciences founded a Folklore Committee with this specific aim in mind. In $193^{8}$, after some internal struggles, De Vries became chairman of this committee. It was the central organization that coordinated the work on a Folklore Atlas for the Netherlands, in close collaboration with the Dutch-speaking Flemish folklorists (Rzoska \& Henkes 2003). As a result of the atlas projects, the emphasis in folklore studies came to be on comparisons with other European 'civilized peoples' at the expense of comparisons with 'primitive peoples', so that folklore studies moved away from anthropology. The focus on Europe was also evident in the aims of the International Association for Ethnology, which was founded in 1935 and partly funded by the German Nazi authorities. Two years later it changed its name to the International Association for European Ethnology and Folklore (IAEEF). Based on the German example, the organization - with Jan de Vries as its Vice-Chairman and then Chairman - referred to the new insights and research methods, particularly in the field of cartography, which were to lead to joint questionnaires and annotations.

The repercussions of the international political developments at the time were also evident in the field of folklore studies. Shortly after the German invasion of the Netherlands in May 1940, both Van der Ven and De Vries published a discourse on folklore studies presenting similar viewpoints. 'Wherever the unity of the Dutch people, preserving our own typically Dutch traditions, is now the subject of discussions and even of heated polemics, that is where the method of folklore research deserves ample attention, which it can make more of a claim to under the present conditions than ever before', Van der Ven stated in September I940 (r940a:244). After an anecdotal sur- vey of the various approaches taken in folklore studies, he emphasized the necessity of cooperation between 'folklorists on both sides of our national borders' (ibid.:253). 'Cooperation among the people of Europe' would not only reinforce 'the Greater Netherlandic tribal consciousness', he felt it would also promote 'a sense of brotherhood among numerous peoples' (ibid.:256).

In I94I De Vries published De zetenschap der volkskunde (The Science of Folklore) with funding from the Department of Education, Science, and the Preservation of Culture. The points he made in this book were in keeping with the arguments he had been presenting for years. After a short historical survey, he gave an extensive account of the goals and methods of the Atlas of Dutch Folklore. In promoting the idea of an Atlas that would cover 'the entire region from Dunkirk to Delfzijl', he made an explicit reference - just as Van der Ven had before him - to his pre-war Greater Netherlandic point of departure. What is more, neither folklorist had problems transforming his Greater Netherlandic ideas into Greater Germanic ones. It was crystal clear to them that folklore studies, which was 'essentially a purely national science', would inevitably lead to 'international cooperation on a broad scale' if only to coordinate the cartographic work in the various countries of Europe (Van der Ven I940a:250-251; De Vries 1941:54).

De Vries and Van der Ven attempted to realize their ambitions in the field of folklore studies within a National Socialist context. This had certain eflects on the contents of their work and the work of other folklorists who were under the spell of a Greater Germanic ideology. After all, the Nazi authorities viewed folklore studies and other disciplines such as archeology and history as an excellent instrument to further their cultural politics and get the peoples of the occupied regions to accept the idea of a Greater Germany (In't Veld I976:I97-217, 269-282). Their publications were filled with allusions to the 'natural sympathy', 'historical ties', 'blood ties' and 'racial ties' that bound the Germanic peoples in general and the Dutch, the Flemish, the Seandinavians and the Germans in particular. This also affected the attitude of these folklorists to anthropological work and to the comparative material It produced.

\section{On Comparisons and Comparability}

As has been noted above, folklorists largely viewed their discipline as a comparative science. They used time-related as well as geographical compurtwons to discern similarities in material and non-material cultural manifestations. This is also evident from an article folklorist Catharina van de Graft 
wrote on the eve of the German occupation. ${ }^{4}$ 'Scientifically speaking, the knowledge of folklore acquired its value when a certain parallelism was discovered between the culture of primitive peoples and the folklore of civilized peoples', she noted in January 1940. This was initially based on evolutionism's assumption that the study of primitive cultures would shed light on earlier stages of the folklorists' own culture and on the survivals that could still be traced. According to Van de Graft, however, by then folklore studies had already been transformed from a study of survivals among 'higher' peoples into the mere study of the customs and rituals of a people, a change that was regretted by this aficionado of the idea of evolution. Although she did see a relation between folklore studies and anthropology, Van de Graft still emphasized that both of these fields 'continue to be very much aware of the enormous distance that separates a primitive person from the less developed members of our own people' (ibid.:43). In other words, no parallels could be drawn between 'primitive' Bushmen and less developed local peasants because they were on different rungs of the evolutionary ladder.

What Van de Graft was formulating so candidly here was to be attributed quite a different significance in the cultural politics of the National Socialists and their sympathizers, who rejected drawing any parallels between Germanic and primitive peoples. Comparisons drawn by folklorists were increasingly narrowed down to certain specific aspects to 'prove' the continued existence of a Germanic national character and properties of the Germanic race ever since Germanic prehistory and over an enormous geographical region where Germanic and Indo-Germanic culture prevailed. The 'Germanic legacy' was purportedly evident in runes, proprietor's marks and symbols that were discovered, 'eternally living signs' that Dutch and German folklorists alike attributed an intrinsic meaning divorced from any context. Comparisons with 'primitive' peoples were taboo. This more or less meant the end of the links with anthropologists, which had already been declining in the second half of the thirties.

On their part, many anthropologists had meanwhile lost interest in folklore studies. The paradigm of evolutionism had given way to other theories like structuralism and, for example in Fischer's work (cf. I936), functionalism. In as much as the work of anthropologists remained comparative, it focused on particular societies and cultures that were deemed akin to one another. But there were other reasons, too. When Steinmetz retired in 1933 his chair was divided up. J.J. Fahrenfort, a lector who continued Steinmetz's anthropological legacy, was a fervent anti-evolutionist. Steinmetz's succes- sor as a professor was H.N. ter Veen, a social geographer who developed a descriptive kind of sociology dubbed 'sociography'. In the thirties and forties, sociographers often dealt with social change in Dutch rural areas, though some also conducted urban studies. They used fieldwork and participant observation as part of their research methods and focused on local contexts without a comparative perspective. Though one might surmise that sociographers would be interested in the field of folklore, the applied character of their work in relation to policy issues prevented them from establishing a close collaboration. However, occasional encounters occurred and many sociographers used folklorists' notions on regional and local singularities.

Jan de Vries cautioned against allowing folklore studies to poach on anthropological territory, leading to a tendency to explain the survivals found among 'civilized peoples' by comparing them to forms of civilization observed among 'primitives' (De Vries I94I:II, I2). The tone underlying these words of caution was initially one of cultural relativism, and when De Vries referred to Robinson Crusoe, who had to learn a great deal before he was able to cope with life as a 'primitive man' - he noted that in principle, there was 'no difference between primitive and civilized man' (ibid.:67). ${ }^{5}$ Under the influence of National Socialism, however, his dissociating himself from anthropology and its subject matter acquired quite a different dimension. The incomparability with primitive peoples was used to glorify the 'Nordic race'.

The epitome of this line of thinking was Hamer, a popular folklore magazine that first came out in October 1940. It was published on the initiative of the Volksche Werkgemeenschap, an organization that was a cover for the Dutch SS (Schutz Staffeln or Protection Squad) that in turn was part of the Ahnenerbe (Ancestral Heritage), the cultural and scientific division of the German SS. Its goal was to make propaganda for the Greater Germanic ideal via applied folklore studies which were mainly published in Hamer (In't Veld I976:265282). In his Preface, Johan Theunisz, the Chairman of the Volksche Werkgemeenwhap, explained 'the aim and purpose' of this new periodical. It is clear that an awareness of 'the essential unity of all Germanic tribes and peoples' was of central importance, and to illustrate this, Theunisz used the instrument of comparison. 'The picture of a Papua out fishing is interesting and foreign to w', he wrote, 'but in the picture of a peasant from Friesland or Stadskanaal out harvesting a crop, we see ourselves at work. His essence and his style are ours' (Theunisz I940:2).

'The theme of this first issue was indeed 'the harvest', and it opened with a prominent article by Van der Ven about 'Dutch harvest customs'. He enthu- 
siastically described some of the 'spontaneous and deeply embedded customs whose rich diversity testifies again and again to the joy our Germanic nature takes in life itself and in our labor'. He referred to harvest festivals as 'reverberations of the olden customs of our forefathers, who bore within them the nobility of their blood and were called to Greater Germanic culture.' 'This is why it is so foolish', he noted, 'to want to compare the Germanic harvest customs with the customs of permanently primitive peoples of another race, who did not have the potential of the Nordic race as their invaluable heritage' (Van der Ven I940b).

Van der Ven presented himself as a supporter of the 'folkish discourse' in which 'the entire body of experience linked to blood and soil' was the central point of departure. In this context as well, the comparison with the anthropological practice served as his source of inspiration, but in the meantime as something he was fervently opposed to. Van der Ven also contributed to the second and third issue of Hamer, but after a conflict with editor-in-chief Nico de Haas about money matters and questions regarding plagiarism, he was to seek other outlets for his 'folkish' ideas. He withdrew from the SS Ahnenerbe but remained within the Nazi milieu. In an editorial in the July I94I issue of Hamer, De Haas responded angrily. Without mentioning Van der Ven's name, he attacked the 'well-known folklorist' who 'objectively studied' some material he found and then went on to compare it 'with material of a similar shape but far from a similar type which others had collected among the Bushmen. They drew their 'conclusions' from these comparisons and enriched their discourse with certain outlandish words and concepts so that it was soon teeming with vegetation demons and fertility rites' (De Haas I94I:2).

De Haas noted though that he had no objections to a comparative method in scientific research, "but there is no purpose to it if phenomena from the Indo-Germanic realm of the cultures of the Nordic race are compared - without taking into consideration the links with the soul of the race - with externally similar phenomena from races and cultures of a totally different nature' (ibid.:3). Ample comparisons were indeed drawn in Hamer, be it within the Germanic - in this case Indo-Germanic - region, in an effort to demonstrate the primal Germanic origin of various customs and phenomena. De Haas was also to engage in theoretical reflection on matters of folklore during the Nazi occupation of the Netherlands (De Haas 194x, 1943). Despite their conflicts, De Haas and Van der Ven both expressed their enthusiasm about 'anything related to race and soil' (Van der Ven I943 [I94I]:6).

ETHNOS, VOL. 68:I, 2003 (PP. II2-I34)

\section{The Primal Source of Germanicness}

De Vries joined in the quest for the well Germanic civilization had sprung from. He became a member of Nazi institutions that wanted to use folklore studies to further their cultural politics (cf. Dekker 1994, 2000). Starting in February 1942, De Vries also wrote articles for Hamer on 'Germanic Gods' and 'The Mystery of the Runes'. His writing style was well balanced and well thought out, and contrasted favorably with the bickering and the pompous and sometimes racist language of many of its other authors. The fact still remains though that he fit in perfectly with the Greater Germanic discourse, which was not as far from his pre-war approach as one is apt to assume in retrospect. After all, De Vries was looking for 'the essence of a people' and this quest soon aroused his interest in the kind of insights that were formulated in the field of 'racial hygiene' (De Vries r93 I:580). His yearning for purity and authenticity, be it still not very explicitly formulated, and his pursuit of the unique qualities of a people were apparently in keeping with elements of National Socialism. In this context, his rational, modern approach to folklore studies could be combined with his romantic worldview.

De Vries's extremism was far surpassed by Nico de Haas, a graphic artist who began to present himself as folklorist in his capacity as editor-in-chief of Hamer. As he explained at length in an article, he saw folk culture as a 'task' that needed to be implemented on the basis of biologically informed folklore studies (De Haas I943). ${ }^{6}$ Urban culture would not be able to do without 'the rural power sources related to it by blood' (ibid.:203), and the authorities would have to serve a steering function by way of 'race-related cultural politics'. In addition to inventorying and preserving, according to De Haas it was the task of folklorists 'to weed out dregs alien to the folk, to keep the world of the folk's traditions free of representations alien to the soul of the race, to exterminate everything that is sick and degenerate, and to prune away the wild' (ibid.:204).

De Haas abhorred folklorists and anthropologists who associated themselves with the 'individualizing' and positivist ideas of French sociologists and anthropologists like August Comte, Emile Durkheim and Lucien LévyBruhl, the last two of whom he emphatically referred to as 'Jewish researchers'. To him, a community was not a rational, social collective, but 'an irrational, organic unit bound in body and soul by a communal legacy: a community of one people and one race' (De Haas I943:201). He never tired of stressing that comparisons should be made in a 'race-related' context. To reinforce the arguments about the incomparability of different 'races', in this case

EIINOS, VOL. 68:I, 2003 (PP. II2-I34) 
Germanic and primitive races, the German Nazi folklorist Karl Weigel was called upon. In an article in Hamer, Weigel noted that 'serious conceptual errors' had been made when people 'replaced the natural mythological way of thinking dating back to the era of the Grimm Brothers with a predominantly anthropological one'. 'Of course' the observation of 'certain similarities between customs of Germanic-Nordic people and those of any of the peoples living at the bottom of the cultural ladder in remote parts of the world' had led to erroneous conclusions (Weigel r943:r9).

This implied a return to the Grimm Brothers and the primal sources of everything Germanic and pagan, and away from comparisons between societies that were not felt to exhibit even the slightest cultural similarities. Backed by publications, collections of photographs, films and exhibitions, all the efforts were focused upon gathering proof of the similarities in a broad field of 'Germanic' sources, which the German Nazis and their allies could use to justify their claims to the territories of other nations such as the Netherlands. From this perspective, folklore studies no longer had much in common with anthropology... unless anthropology came closer to folklore studies. In so far as there was any evidence of this, it was solely in the field of physical anthropology. $^{7}$

After the end of World War II, folklore studies and anthropology seemed to be further apart than ever. The way National Socialism had propagated folklore studies for its own political purposes made the relatively new discipline a very controversial field outsiders were not eager to venture into. Moreover, the fact that some prominent folklorists from the Netherlands and abroad had been so willing to collaborate with the Nazis had immense effects on the post-war developments in the discipline. Immediately after the liberation, Jan de Vries was dismissed as professor and dropped from the membership list of the Royal Netherlands Academy of Arts and Sciences. Van der Ven was asked to leave the NNBA board and hence give up his chair of the Folklore Section. He was also temporarily prohibited from publishing anything at all. There were no longer any professors at the universities to further develop the discipline. It was only the Folklore Committee of the Royal Academy that continued its work on the Folklore Atlas.

For the time being, there was little evidence of any post-war cooperation between anthropologists and folklorists in the Netherlands, although there were a few exceptions. Shortly after the war, anthropologist Johannes Fahrenfort and folklorist Catharina van de Graft jointly wrote a two-volume work on 'funeral customs and culture' (I947), focusing on funeral customs among 'primitive' and 'semi-civilized' peoples as well as in Europe in general and the Netherlands in particular. It was not until the end of the sixties - with the introduction of an endowed chair for European Ethnology at the University of Amsterdam - that there was to be structural contact between folklore studies and anthropology again. Anthropologists were put in charge of the endowed chair, which was filled by August Johan Bernet Kempers. He had made a name for himself as archaeologist and cultural historian in the former Netherlands East Indies, now Indonesia. At the time, he was also the Director of the Netherlands Open Air Museum. The process of cultural preservation, transference and change played a central role in his dynamic approach to folklore studies. He was not interested in the static but in the process-related aspects of folk culture, as is now common practice in folklore studies. His influence nonetheless remained quite limited. He never did succeed in bringing folklore studies more clearly to the fore, and his position in anthropological circles was a marginal one (Van der Kooi 1994:333-336). After his retirement, the endowed chair was never filled again. It is only very recently that folklore studies made a re-appearance in Dutch universities.

\section{Closing Comments}

Much as the development of anthropology can be linked to colonialism, the rise of folklore studies is closely connected to nationalism. As a colonial power, the Netherlands had a cultural political and economic interest in the study of societies and cultures in the remote corners of its kingdom. And indeed anthropology attained a far more dominant position in the Dutch academic world than folklore studies. This was not the case everywhere in Europe. In a country like Sweden without any colonies, anthropology was a peripheral discipline and folklore studies occupied a more central position (cf. Gerholm r995; Schippers r995). In Central and Eastern European countries, where national and ethnic identities could be confused and complex, folklore studies also developed into a full-fledged discipline in an academic as well as a cultural political sense (cf. Hofer I968; Kürti I996).

National Socialism served as a strong stimulus for folklore studies in Germany as well as the countries it was occupying such as the Netherlands. The SS Ahnenerbe cultural politics provided folklorists with recognition and unexpected means to further their interests. Several of them jumped on the bandwagon, convinced that their work would be to the benefit of the Dutch people within the context of a Greater Germany (Henkes \& Rzoska 2003). In the post-warNetherlands and elsewhere as well, this was to put folklore studies 
in a highly unfavorable light, which did not exactly promote an open exchange of ideas or the further advancement of folklore studies as an academic discipline.

Anthropologists were similarly confronted with a political legacy, but within the context of a post-colonial nation they had more leeway to gradually dissociate themselves from the colonial heritage. The de-colonization process had certain repercussions on the practice of anthropology. After Indonesia gained independence in 1949, many anthropologists relocated to other fieldwork sites and some anthropologists who had been working as colonial civil servants turned to development assistance and international aid (Kloos r975). In addition, growing numbers of anthropologists preferred to do their fieldwork closer to home, in Europe or the Netherlands itself (cf. Van Ginkel I997, I998). In general, anthropologists became more critical and reflexive as regards the implications their work could have.

This transformation took place at virtually the same time as the one in the folklore discipline, where a new and critical generation was emerging that was eager to abandon the outdated old premises. This was not only the case in the Netherlands, the same thing happened in Germany starting at the end of the seventies under the leadership of Hermann Bausinger in Tübingen. In France and Sweden, critical discussions had already taken place even earlier about the methods and aims of folklore studies (cf. Dekker r994:358ff.). Dutch folklorists turned to cultural anthropology and history for their methodological and theoretical inspiration, and anthropologists in turn were attracted by the huge amount of factual information that folklorists had at hand (Verrips I975, 1977). Starting in the mid-seventies, there was consequently once again a cautious rapprochement between the relatively small number of folklorists in the Netherlands and their colleagues in the fields of anthropology and history.

The same trend was also evident elsewhere in Europe, where the field of folklore studies was increasingly referred to as European ethnology, and modernday ethnologists were combining insights from the two disciplines in a highly productive way. Thus, writing in the $\mathrm{x} 98 \mathrm{os}$, Segalen contends that 'l'ethnologie contemporaine de la France' has been rejuvenated by the interests of researchers in anthropological concepts and theories (Segalen r986:3). Yet at the same time the rapprochement between folklorists and anthropologists still has not led to joint efforts to arrive at a more structural exchange. Notwithstanding the interest in inter-disciplinary, multi-disciplinary, supra-disciplinary and nondisciplinary meetings, the borders dividing the disciplines are not easy to cross. What makes it difficult to do so is the articulation of 'disciplinary identities': an orientation to disciplinary history, research methods, theories and concepts, networks, organizations, publication outlets and meetings. Paradoxically, the greater the measure of rapprochement, the greater the need to emphasize how disciplines differ. Not doing so would mean giving up disciplinary identity and hence the reason for a discipline's existence. Those who have won a position in the existing academic field perceive this as threatening. Still we think that crossing disciplinary boundaries and collaborations between European ethnology and anthropology on the basis of common themes and approaches will be necessary to enrich and renew both fields of research.

\section{Acknowledgments}

We would like to express our gratitude to Kitty Roukens, Martijn Eickhof and Susan Legêne for their comments on an earlier version of this article. Thanks also to Wilhelm Östberg and three anonymous reviewers for their thoughtful criticisms and suggestions.

\section{Notes}

I. As early as I920, Van der Ven noted 'that a wide range of ethnological material is still waiting in the Netherlands for someone to classify and process it' and that 'the anthropology of the Netherlands [...] should be approached on a wider scale and with more ample funding and preferably simultaneously from all sides' (I920:I62).

2. To avoid confusion, we use the concepts of folklore studies and anthropology throughout this article. In Dutch, folklore studies used to be called folklore or more commonly volkskunde, but these terms have recently been replaced by Nederlandse etnologie. In the period under consideration here, social and cultural anthropology could be referred to as antropologie, ethnologie or volkenkunde. The latter two concepts have meanwhile become outdated. We do not deal with the field of physical anthropology in this article.

3. Van der Ven derived the term 'biological folklorist' from the French folklorist and anthropologist Arnold van Gennep (I924:33-34). As is clear from the writings of the ethnographer Fischer (I933:432) and the folklorist Van de Graft (I940:4), other authors also adopted this metaphor of the botanist gathering data out in the field, i.e. in the natural environment.

4. Van de Graft was a prominent and prolific folklorist. Though not affiliated with any specific institute, she was the author of numerous publications and was invited to join various committees and attend many international conferences (Van der Zeijden I999).

5. 'They use their judgment in much the same way,' he stated, 'primitive people just have less experiential material, and modern man has an enormous head start in this respect' (De Vries I941:67-68).

6. It should be clear that the biological metaphor in the context of Hamer has a totally different meaning than the biological metaphor used earlier by Van der Ven and others in much the same way as it was used by Arnold van Gennep. 
7. Little is known about the wartime activities of Dutch cultural anthropologists However, H.Th. Fischer was a strong opponent of racist and National Socialist ideologies and in 1944 was suspended from all duties by the German occupation authorities.

\section{References}

Belmont, N. 1979. Arnold Van Gennep: The Creator of French Ethnography. Transl. D. Coltman. Chicago: The University of Chicago Press.

Cuisenier, J. \& M. Segalen. I986. Ethnologie de la France. Paris: Presses Universitaires de France.

De Haas, N. I94I. Folklore en volkskunde. Hamer, r:2-3.

- I943. Volkscultuur als taak (Volkskunde op biologischen grondslag). Groot Nederland, 4I:I93-204.

De Jong, A. I992. Het openluchtmuseum tussen theater en theorie. Museumvisie, I6:157-I6r.

De Ruijter, A. r98r. The Leiden School of Anthropology: Historical Perspective. In The Nature of Structure, edited by G.A. Moyer et al., pp. 26-54. Leiden: Institute of Cultural and Social Studies.

De Vries, J. r929a. Een dringende eisch. De Gids, 93:84-102.

- I929b. De verhouding tusschen folklore en de hoogere cultuur. Mensch en Maatschappij, $5: 263-265$.

-. I93I. Review of the I5th edition of H.F.K. Günther's Rassenkunde des deutschen Volkes (1930). Mensch en Maatschappij, 7:57-580.

- I932. Volkskunde en volkenkunde als hulpwetenschappen der godsdienst-geschiedenis. Mensch en Maatschappij, 8:452-464.

- 1933. Review of Schrijnen's revised edition of Nederlandsche volkskunde, vol. 2, Mensch en Maatschappij, 9:6r9-621.

- I934. De volkskunde op een keerpunt. Nederlands Tijdschrift voor Volkskunde, 39: 3-30.

- I937a. Inleiding. In Volk van Nederland, edited by J. de Vries et al., pp. I-22. Amsterdam: Elsevier.

- 1937b. Nieuwe wegen in de studie der volkskunde. Nederlands Tijdschrift voor Volkskunde, 4I:3-29.

-. 1937c. Terugblik en uitzicht. In Volk van Nederland, edited by J. de Vries et al., pp. 404-4I4. Amsterdam: Elsevier.

-. I94I. De wetenschap der volkskunde. Amsterdam: Elsevier.

Dekker, T. 1994. Het Rijksinstituut voor Nederlandsche Taal en Volkscultuur. In $A n$ tiquaren, liefhebbers en professoren: Momenten uit de geschiedenis van de Nederlandse Volkskunde, edited by T. Dekker et al., pp. 343-374. Amsterdam: P.J. Meertens Institute.

-. 2000. Ideologie en volkscultuur ontkoppeld: een geschiedenis van de Nederlandse volkskunde. In Volkscultuur: Een inleiding in de Nederlandse etnologie, edited by $\mathrm{T}$. Dekker et al., pp. I3-65. Nijmegen: Uitgeverij suN.

Ellen, R.F. 1976. The Development of Anthropology and Colonial Policy in the Netherlands, I800-1960. Journal of the History of the Behavioral Sciences, 12:303-324.

Fahrenfort J.J. \& C.C. van de Graft. I947. Dodenbezorging en cultuur. 2 volumes. Amsterdam: Ploegsma.
Fischer, H.Th. I933. Drieerlei soort religieuze volkskunde. Mensch en Maatschappij, 9:429-436.

-. 1936. De moderne ethnologie als historische wetenschap. Groningen: J.B. Wolters.

Gansohr-Meinel, H. 1995. Die Landesstelle des Atlas der deutschen Volkskunde in Bonn und ihre Bedeutung für die Rheinische 'Volks-' und 'Grenzlandforschung' der zwanziger und dreissiger Jahre, Rheinische Vierteljahrsblätter, 59:271-304.

Gerholm, T. x995. Sweden: Central Ethnology, Peripheral Anthropology. In Field work and Footnotes: Studies in the History of European Anthropology, edited by H.F. Vermeulen \& A.A. Roldán, pp. I59-170. London: Routledge.

Henkes, B. \& B. Rzoska. 2003. Volkskunde und 'Volkstumpolitik' der SS in den Niederlanden: H.E. Schneider und seine 'Grossgermanischen' Ambitionen für den niederländischen Raum. In Griff nach dem Westen: Die 'Westforschung' der völkischnationalen Wissenschaften zum nordwesteuropäischen Raum (19r9-I960), edited by B. Diets et al. Münster: Waxmann Verlag.

Hofer, T. I968. Anthropologists and Native Ethnographers in Central European Villages. Current Anthropology, 9:3II-356.

In't Veld, N.K.C.A. 1976. De SS en Nederland: Documenten uit SS-archieven 1935 I945, deel r. The Hague: Matinus Nijhoff.

Kloos, P. r975. Anthropology and Non-Western Sociology in the Netherlands. In Current Anthropology in the Netherlands, edited by P. Kloos \& H.J.M. Claessen, pp ro-29. Rotterdam: Anthropological Branch of the Netherlands Sociological and Anthropological Society.

Kürti, L. I996. Homecoming: Affairs of Anthropologists in and of Eastern Europe. Anthropology Today, I2:II-I5.

Rasch, J. 1930. Centra voor volkskunde in Nederland. Eigen Volk, 2:75-79.

Rzoska, B. \& B. Henkes. 2003. Das Volk wurde neu entdeckt!: Volkskunde und die 'grossgermanische' Kulturpolitik in Flandern (I934-1944). In Griffnach dem Westen: Die 'Westforschung' der völkisch-nationalen Wissenschaften zum nordwesteuro-päischen Raum (I9I9-I960), edited by B. Diets et al. Münster: Waxmann Verlag.

Schippers, T.K. I995. A History of Paradoxes: Anthropologies of Europe. In Fieldwork and Footnotes: Studies in the History of European Anthropology, edited by H.F. Vermeulen \& A.A. Roldán, pp. 234-246. London: Routledge.

Segalen, M. 1986. Current Trends in French Ethnology. Ethnologia Europaea, 16:3-24

-. 1999. Anthropology at Home and in the Museum: The Case of the Musée National des Arts et Traditions Populaires in Paris. Focaal, 34:8I-94.

Steinmetz, S.R. x929. Algemeene beschouwing over ethnologie en folklore. Mensch en Maatschappij, 5:26I-263.

Theunisz, J. I940. Ten Geleide. Hamer, I:2.

Tylor, E.B. I87I. Primitive Culture. London: J. Murray.

Van de Graft, C.C. I940. De folklore als wetenschap. De Gids, I04(r):36-50.

Van der Kooi, J. I994. De volkskunde aan de Nederlandse universiteiten: Een historisch overzicht. In Antiquaren, liefhebbers en professoren: Momenten uit de geschiedenis van de Nederlandse Volkskunde, edited by T. Dekker et al., pp. 323-342. Amsterdam: P.J. Meertens Institute.

Van der Ven, D.J. r920. Neerlandsch volksleven. Zaltbommel: Uitg.-Mij en Boekhandel v/h P.M. Vink.

ETHNOS, VOL. 68:I, 2003 (PP. II2-I34) 
-. 1927. Een oriënteering ten opzichte van scheidings- en opnemingsritueel in de Boerenbruiloft. Mensch en Maatschappij, 3:116-130 and 216-233.

- I929a. Methode van onderzoek bij de bestudeering van volksgebruiken. Mensch en Maatschappï, 5:272-276.

-. 1929b. Van vrijen en trouzven op 't boerenland. Amsterdam: De Spieghel.

- I930a. De folklore als wetenschap in Nederland. Mensch en Maatschappij, 6:457475 .

- 1930b. Heemschut, volkskunst en de drooglegging der Zuiderzee. Amsterdam: F. van Rossum.

-. r940a. Geen volksopbouw zonder volkskunde. Haagsch Maandblad, 34:239-256.

—. I94ob. Bij de laatste schoof. Hamer, I:4-7.

-. I943 [194I]. De Heemliefde van het Nederlandsche volk. 2nd edition. Naarden: Rutgers.

Van der Zeijden, A. I999. Cornelia Catharina van de Graft (I874-1969): Een vrouw in de volkskunde. In Jaarboek voor Vrouwengeschiedenis, edited by B. Henkes et al. Amsterdam: Stichting Beheer IISG.

Van Gennep, A. r924. Le Folklore: Croyances et coutumes populaires françaises. Paris: Stock.

Van Ginkel, R. 1997. Notities over Nederlanders: Antropologische reflecties. Amsterdam: Boom.

- I998. Observations from Within, Observations from Without: The Dutch in Anthropological Perspective. Ethnologia Europaea, 28:67-89.

Verrips, J. r975. Volkskunde, antropologie en allianties. Volkskundig Bulletin, r:19-46. 一. 1977. Volkskunde en antropologie. Sociodrome, 5:7-rr.

Voskuil, J.J. I98r. Het tijdelijke met het eeuwige verwisseld, of: op de klank van de midwinterhoorn de eeuwigheid in. Volkskundig Bulletin, 7:I-50.

Wagemakers, T. I996. Het Vaderlandsch Historisch Volksfeest: Over D.J. van der Ven, massatoerisme en de moderne folklore. Jaarboek Nederlands Openluchtmuseum 2:I7I-I87.

Weigel, K.Th. 1943. Volksgebruik en zinnebeeld I. Hamer, 3:I9-2 I. 